\title{
Pathogenic Factors in Bronchopulmonary Dysplasia
}

\author{
KATHERINE MCCARTHY, MADHU BHOGAL, MICHAEL NARDI, AND DAVID HART (40) \\ Department of Pediatrics, New York University Medical School, 550 First Avenue, New York, New York, USA
}

\begin{abstract}
Summary
Serum factors related to oxygen exposure were studied in $\mathbf{5 6}$ full-term cord blood samples and in 69 newborn infants of varying gestational age (GA). Serum malondialdehyde (MDA), which reflects membrane lipid peroxidation, was elevated during the first $2 \mathrm{~d}$ of life and rose to a peak at 3-5 d of life. This peak value was unrelated to $\mathrm{GA}$ or to assisted ventilation.

The serum antioxidant, vitamin $\mathrm{E}$, showed a significant rise by 6-10 d, and came into the adult range after d 11. Vitamin $E$ levels did not correlate with $G A$, assisted ventilation, or the development of bronchopulmonary dysplasia (BPD). Serum ceruloplasmin, another antioxidant, was measured both by activity assay and by protein concentration assay. Little activity was found in cord blood. Ceruloplasmin activity increased during the first $48 \mathrm{~h}$ of life, and both activity and protein concentration correlated with GA at that time. Infants who subsequently developed $B P D$ had a less active protein than infants on ventilators who did not develop BPD. In addition, activity and protein levels on 3-5 d were lower in infants on ventilators than in those not requiring assisted ventilation.

Serum levels of $\alpha-1-\mathrm{AP}$ activity and protein concentration were also correlated with GA during the first $48 \mathrm{~h}$ of life. The less mature infants had levels of activity and protein which were significantly less than the more mature infants and significantly less than the full-term cord values. The proportion of active protein correlated with GA at 3-5 d, indicating that the less mature infants had a lower proportion of active protein. All infants had activity and protein levels within the normal range for healthy adults by 6-10 d.
\end{abstract}

\section{Abbreviations}

$\alpha$-1-AP, alpha-1-antiprotease

BPD, bronchopulmonary dysplasia

GA, gestational age

MDA, malondialdehyde

OA, oxidase activity

PAM, pulmonary alveolar macrophages

RDS, respiratory distress syndrome

TIC, trypsin inhibitory capacity

Neonatal RDS is a life-threatening disorder of the premature infant. Respiratory therapy is essential for many infants. This therapy has been associated with pathologic findings in the lungs, starting as early as $48-72 \mathrm{~h}(22)$ after initiation of therapy. The respirator-induced lung disease is known as BPD (25).

Highly reactive oxygen metabolites are thought to mediate pathologic changes in lungs exposed to oxygen $(4,33)$. Herein we show that all infants, regardless of $\mathrm{GA}$, have evidence of oxidative damage during the first few days after birth, and that premature infants have much lower levels of antioxidants than adults.
Neutrophil and macrophage invasion of the lung follows exposure to oxygen $(10,21,22)$. In addition to releasing oxygen radicals, these cells elaborate elastase, a proteolytic enzyme which is primarily inhibited by $\alpha-1-\mathrm{AP}$. We demonstrate that $\alpha-1-\mathrm{AP}$ protein concentration is decreased in the most immature babies, and that this protein has diminished activity in infants on assisted ventilation, a finding consistent with oxygen radical mediated inactivation $(2,3)$. Our data support the evolving concept of a multifactorial cause for the chronic damage done to the premature lung exposed to oxygen.

\section{MATERIALS AND METHODS}

Patients. From July 1979 to February 1982, all babies admitted to New York University Hospital or Bellevue Hospital were eligible for study if their parents gave informed consent. A total of 69 babies were enrolled ( 41 males, 28 females). GA determined by Dubowitz scoring (6) ranged from 27 wk to postmature. Birth weights were 790-3090 g. Infants were fed proprietary formulas, but were not given additional vitamin E. RDS developed in 38 infants by clinical and radiographic criteria (1). Thirteen (three with non-RDS lung disease) required assisted ventilation for $4 \mathrm{~d}$ or less and 28 were treated with mechanical ventilation for more than $4 \mathrm{~d}$, or until demise. Radiographic evidence of BPD (7) developed in six infants.

Blood samples were obtained from non-heparinized umbilical venous catheters, from venipuncture, or from venous capillary collections. Blood was collected three times during the first week of life, then weekly for the remainder of hospitalization. Whenever possible, blood was also collected at the time of follow-up out patient visits. Cord bloods were obtained from 56 normal full term newborns at delivery by venipuncture of the umbilical vein. Blood was immediately centrifuged at $3000 \mathrm{r} / \mathrm{min}$ for 10 min and the serum stored at $-70^{\circ} \mathrm{C}$ until used for the assays, which were performed in blind fashion.

Laboratory Techniques. MDA levels were determined by reaction with thiobarbituric acid according to the technique of Yoshioka et al. (38). Vitamin E levels were determined as described by Fabianek et al. (9).

Ceruloplasmin activity was measured from its $\mathrm{OA}$, by the technique of Schosinsky et al. (30) with o-dianisidine dihydrochloride as the substrate. Ceruloplasmin protein concentration was determined by radial immunodiffusion assay (M-Partigen, Calbiochem-Behring Corp., LaJolla, CA).

$\alpha-1-\mathrm{AP}$ activity was measured as TIC, as described by Talamo et al. (34). $\alpha$-1-AP protein concentration was determined by radial immunoassay using a technique described by Mancini et al. (19) (Quantiplate, Kallestad Laboratories, Inc., Chaska, MN). Results were expressed as a percentage of a pool of serum from ten normal adult males.

Statistics. All results are expressed as mean value \pm standard error of the mean. Statistical analysis included linear regression, paired, and unpaired $t$ tests. The Bonferroni $t$ statistic was used 
whenever more than one $t$ test was applied to a family of data (23).

\section{RESULTS}

Malondialdehyde. The mean MDA level (Table 1) during the first $48 \mathrm{~h}$ of life from newborn infants was significantly higher than either the mean cord value or the mean value from healthy adults. This 1-2-d level was not correlated with GA, birth weight, or with assisted ventilation. Sequential samples showed that a significant increase in the level of MDA occurred by 3-5 d of life. This peak level at 3-5 d was not correlated with GA, assisted ventilation, or with the development of BPD. Infants on ventilators, including those who subsequently developed BPD, had lower levels of MDA, although this difference was not significant.
MDA levels showed a significant decline by 11-17 d in all infants. Mean levels on 25-31 d and on 32-38 d were similar to levels found in healthy adults, even in those infants who still required assisted ventilation for BPD.

Vitamin E. Samples from 38 premature infants (GA, 27-36 wk) demonstrated a level of vitamin $E$ (Table 2) in the first $48 \mathrm{~h}$ of life which was significantly less than the adult normal. There was a significant increase in vitamin $E$ content when $1-2 d$ was compared with 6-10 d. A further increase into the adult normal range was evident after $\mathrm{d} 11$. Vitamin $\mathrm{E}$ levels did not correlate with GA, assisted ventilation, or with the development of BPD.

Ceruloplasmin. OA determinations (Table 3 ) were significantly lower in cord samples than in healthy adult samples. This cord ceruloplasmin was only $44.7 \%$ active $(\mathrm{O} / \mathrm{A} /$ Protein ratio; each expressed as a percentage of adult mean).

Table 1. Malondialdehyde $(\mathrm{nM} / \mathrm{ml})^{*}$

\begin{tabular}{|c|c|c|c|c|c|c|c|}
\hline & \multicolumn{7}{|c|}{ Days of life } \\
\hline & $1-2$ & $3-5$ & $6-10$ & $11-17$ & $18-24$ & $25-31$ & $32-38$ \\
\hline $\begin{array}{l}\text { All infants } \\
\qquad(n)\end{array}$ & $\begin{array}{l}16.63 \pm 1.70 \dagger \\
(28)\end{array}$ & $\begin{array}{l}25.82 \pm 3.09 \ddagger \\
(16)\end{array}$ & $\begin{array}{l}18.23 \pm 1.88 \\
(26)\end{array}$ & $\begin{array}{l}12.27 \pm 1.87^{\$ !} \\
(13)\end{array}$ & $\begin{array}{l}10.36 \pm 1.75 \\
(5)\end{array}$ & $\begin{array}{l}8.76 \pm 1.27 \\
(10)\end{array}$ & $\begin{array}{l}6.78 \pm 0.55 \\
(10)\end{array}$ \\
\hline $\begin{array}{l}\text { Gestational age } \\
\leqq 32 \mathrm{wk}\end{array}$ & $13.92 \pm 1.60$ & $22.2 \pm 3.83$ & $19.22 \pm 2.66$ & $8.14 \pm 1.53$ & 8.42 & $10.26 \pm 1.85$ & $6.39 \pm 0.83$ \\
\hline$(n)$ & (12) & (4) & (14) & (5) & (1) & (3) & (5) \\
\hline $\begin{array}{l}\text { Gestational age } \\
\geqq 33 \mathrm{wk}\end{array}$ & $18.67 \pm 2.66$ & $27.03 \pm 3.93$ & $17.08 \pm 2.73$ & $14.86 \pm 2.54$ & $10.84 \pm 2.16$ & $8.11 \pm 1.65$ & $7.23 \pm 0.76$ \\
\hline$(n)$ & (16) & (12) & (12) & (8) & (4) & (7) & (5) \\
\hline $\begin{array}{l}\text { No assisted ventila- } \\
\text { tion }\end{array}$ & $18.48 \pm 4.32$ & $27.05 \pm 5.83$ & $14.00 \pm 1.70$ & $14.61 \pm 2.63$ & $10.36 \pm 1.75$ & $8.76 \pm 1.27$ & \\
\hline$(n)$ & (8) & (7) & (12) & (8) & (5) & $(10)$ & (8) \\
\hline $\begin{array}{l}\text { Assisted ventilation } \\
\quad(n)\end{array}$ & $\begin{array}{l}15.89 \pm 1.71 \\
(20)\end{array}$ & $\begin{array}{l}24.87 \pm 3.42 \\
(9)\end{array}$ & $\begin{array}{l}21.86 \pm 2.89 \\
(14)\end{array}$ & $\begin{array}{l}8.54 \pm 1.52 \\
(5)\end{array}$ & $\ldots$ & $\begin{array}{l}\ldots \\
(0)\end{array}$ & $\begin{array}{c}6.03 \pm 2.47 \\
(2)\end{array}$ \\
\hline $\begin{array}{l}\text { Bronchopulmonary } \\
\text { dysplasia }\end{array}$ & $9.77 \pm 1.98$ & $19.59 \pm 3.96$ & $21.48 \pm 5.55$ & $11.45 \pm 1.95$ & $\ldots$ & $\ldots$ & $6.03 \pm 2.47$ \\
\hline$(n)$ & (4) & (3) & (6) & (2) & $(0)$ & $(0)$ & (2) \\
\hline
\end{tabular}

* Values are expressed as mean \pm SEM; $(n)$, number. Full term cord samples (55) $10.37 \pm 0.77$ and healthy adults $(30) 8.13 \pm 0.18$

$\dagger P<0.01$ vs cord, $P<0.01$ vs adult.

$\ddagger P<0.05$ unpaired, $P<0.01$ paired $(n=12)$ vs d $1-2$.

$\S P<0.01$ unpaired, $P<0.05$ paired $(n=8) v s \mathrm{~d} 3-5.1 P<0.05$ paired $(n=8) v s 6-10 \mathrm{~d}$

Table 2. Vitamin E levels $(\mathrm{mg} / \mathrm{dl})$ in premature infants (gestational age 27-36 wk)*

\begin{tabular}{|c|c|c|c|c|c|}
\hline & \multicolumn{5}{|c|}{ Days of life } \\
\hline & $1-2$ & $3-5$ & $6-10$ & $11-31$ & $32-73$ \\
\hline $\begin{array}{l}\text { All infants } \\
\qquad(n)\end{array}$ & $\begin{array}{l}0.30 \pm 0.05 \dagger \\
(14)\end{array}$ & $\begin{array}{l}0.30 \pm 0.04 \\
(2)\end{array}$ & $\begin{array}{l}0.66 \pm 0.07 \ddagger \\
(18)\end{array}$ & $\begin{array}{l}0.87 \pm 0.12 \\
(11)\end{array}$ & $\begin{array}{l}1.14 \pm 0.08 \\
(8)\end{array}$ \\
\hline $\begin{array}{l}\text { Gestational age } \\
\leqq 32 \mathrm{wk}\end{array}$ & $0.26 \pm 0.08$ & $\cdots$ & $0.75 \pm 0.07$ & $0.88 \pm 0.21$ & $1.14 \pm 0.09$ \\
\hline$(n)$ & $(8)$ & $(0)$ & $(10)$ & (5) & (7) \\
\hline $\begin{array}{l}\text { Gestational age } \\
33-36 \mathrm{wk}\end{array}$ & $0.37 \pm 0.06$ & $0.30 \pm 0.04$ & $0.54 \pm 0.12$ & $0.86 \pm 0.15$ & 1.16 \\
\hline$(n)$ & (6) & (2) & $(8)$ & (6) & (1) \\
\hline $\begin{array}{l}\text { No assisted ventilation } \\
\qquad(n)\end{array}$ & $\begin{array}{l}0.34 \pm 0.13 \\
(8)\end{array}$ & 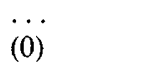 & $\begin{array}{l}0.69 \pm 0.08 \\
(10)\end{array}$ & $\begin{array}{l}0.88 \pm 0.13 \\
(10)\end{array}$ & $\begin{array}{l}1.14 \pm 0.08 \\
(8)\end{array}$ \\
\hline $\begin{array}{l}\text { Assisted ventilation } \\
\quad(n)\end{array}$ & $0.25 \pm 0.11$ & $\begin{array}{l}0.30 \pm 0.04 \\
(2)\end{array}$ & $0.61 \pm 0.11$ & $\begin{array}{r}0.72 \\
(1)\end{array}$ & (0) \\
\hline $\begin{array}{l}\text { Bronchopulmonary } \\
\text { dysplasia }\end{array}$ & 0.15 & $\ldots$ & $0.43 \pm 0.19$ & 0.72 & $\ldots$ \\
\hline$(n)$ & (1) & $(0)$ & (2) & (1) & $(0)$ \\
\hline
\end{tabular}

* Values are expressed as mean \pm SEM and $(n)$, number. Healthy adults $(30) 1.05 \pm 0.05$.

$\dagger P<0.001$ vs adults.

$\ddagger P<0.01$ vs $1-2 \mathrm{~d}$. 
Table 3. Ceruloplasmin*

\begin{tabular}{|c|c|c|c|c|c|}
\hline & & \multicolumn{4}{|c|}{ Days of life } \\
\hline & & $1-2$ & $3-5$ & $6-10$ & $11-17$ \\
\hline \multirow[t]{4}{*}{ All infants } & $\mathrm{OA}$ & $33.6 \pm 8.27$ & $38.0 \pm 6.55$ & $31.4 \pm 3.44$ & $45.2 \pm 5.15$ \\
\hline & Protein & $10.6 \pm 2.18$ & $14.1 \pm 2.01$ & $11.4 \pm 0.91$ & $13.0 \pm 1.60$ \\
\hline & $\mathrm{OA} / \mathrm{P}$ & $65.7 \pm 9.1$ & $75.3 \pm 6.9$ & $77.7 \pm 8.4$ & $102.0 \pm 8.7$ \\
\hline & $(n)$ & $(22)$ & $(23)$ & (19) & (9) \\
\hline \multirow{3}{*}{$\begin{array}{l}\text { Gestational age } \\
\leqq 32 \mathrm{wk}\end{array}$} & $\mathrm{OA}$ & $5.4 \pm 3.21 \dagger$ & $9.7 \pm 2.67$ & $26.4 \pm 4.64$ & $37.5 \pm 11.56$ \\
\hline & Protein & $2.5 \pm 1.47 \dagger$ & $7.3 \pm 1.32$ & $11.8 \pm 2.15$ & $12.1 \pm 3.18$ \\
\hline & $\mathrm{OA} / \mathrm{P}$ & $23.3 \pm 11.1$ & $36.6 \pm 5.50$ & $59.9 \pm 12.5$ & $86.2 \pm 9.52$ \\
\hline Gestational age & $(n)$ & (7) & (4) & $(7)$ & (3) \\
\hline \multirow{3}{*}{$\geqq 33 \mathrm{wk}$} & $\mathrm{OA}$ & $46.8 \pm 10.47 \ddagger$ & $43.9 \pm 7.21$ & $34.2 \pm 4.67$ & $49.0 \pm 5.30$ \\
\hline & Protein & $14.4 \pm 2.62$ & $15.5 \pm 2.29$ & $11.2 \pm 0.81$ & $13.5 \pm 2.00$ \\
\hline & $\mathrm{OA} / \mathrm{P}$ & $85.5 \pm 8.37 \ddagger$ & $\begin{array}{l}88.7 \pm 9.20 \\
(19)\end{array}$ & $88.0 \pm 10.3$ & $110.0 \pm 11.2$ \\
\hline \multirow{4}{*}{ No assisted ventilation } & $\begin{array}{l}(n) \\
\mathrm{OA}\end{array}$ & $\begin{array}{l}(15) \\
39.1 \pm 11.91\end{array}$ & $52.6 \pm 10.22$ & $32.9 \pm 6.14$ & $\begin{array}{l}(6) \\
440+667\end{array}$ \\
\hline & $\begin{array}{l}\text { OA } \\
\text { Protein }\end{array}$ & $13.2 \pm 3.00$ & $19.2 \pm 3.13$ & $10.7 \pm 1.15$ & $\begin{array}{l}44.0 \pm 6.61 \\
12.4 \pm 2.01\end{array}$ \\
\hline & $\begin{array}{l}\text { Protein } \\
\mathrm{OA} / \mathrm{P}\end{array}$ & $75.7 \pm 9.60$ & $82.1 \pm 10.1$ & $85.1 \pm 14.6$ & $\begin{array}{c}12.4 \pm 2.01 \\
104.4 \pm 11.10\end{array}$ \\
\hline & $(n)$ & (9) & $(12)$ & (10) & (7) \\
\hline \multirow{4}{*}{ Assisted ventilation } & $\mathrm{OA}$ & $29.8 \pm 11.59$ & $22.0 \pm 4.82$ & $29.7 \pm 2.90$ & $49.0 \pm 0.95$ \\
\hline & Protein & $8.8 \pm 3.04$ & $8.6 \pm 0.92$ & $12.3 \pm 1.44$ & $15.2 \pm 1.20$ \\
\hline & $\mathrm{OA} / \mathrm{P}$ & $58.8 \pm 14.0$ & $67.9 \pm 9.50$ & $69.4 \pm 7.2$ & $94.1 \pm 9.20$ \\
\hline & $(n)$ & (13) & $(11)$ & (9) & $(2)$ \\
\hline \multirow{4}{*}{$\begin{array}{l}\text { Assisted ventilation } \\
\text { no BPD }\end{array}$} & $O A$ & $38.1 \pm 14.12$ & $25.9 \pm 6.10$ & $28.2 \pm 4.07$ & \\
\hline & Protein & $11.4 \pm 3.58$ & $8.8 \pm 1.17$ & $10.5 \pm 0.55$ & \\
\hline & $\mathrm{OA} / \mathrm{P}$ & $76.5 \pm 13.63$ & $77.7 \pm 11.21$ & $76.0 \pm 7.84$ & \\
\hline & $(n)$ & $(10)$ & $(8)$ & $(6)$ & $(0)$ \\
\hline \multirow[t]{4}{*}{ BPD } & $\mathrm{OA}$ & $2.1 \pm 2.1$ & $11.7 \pm 2.55$ & $32.5 \pm 3.45$ & $49.0 \pm 0.95$ \\
\hline & Protein & $0.15 \pm 0.15$ & $8.0 \pm 1.57$ & $15.9 \pm 3.72$ & $15.2 \pm 1.20$ \\
\hline & $\mathrm{OA} / \mathrm{P}$ & $0^{\S}$ & $41.7 \pm 2.7$ & $56.1 \pm 13.6$ & $93.9 \pm 9.1$ \\
\hline & $(n)$ & (3) & (3) & (3) & $(2)$ \\
\hline
\end{tabular}

* Abbreviations: OA, oxidase activity $(\mathrm{IU} / \mathrm{ml}) ; \mathrm{P}$, protein $(\mathrm{mg} / \mathrm{dl})$; BPD, bronchopulmonary dysplasia. Values are expressed as mean $\pm \mathrm{SEM}$ and $(n)$, number. Healthy adults: OA (12) $120.7 \pm 7.5$ and protein, $20-60$ normal range. Full term cord samples: OA $(56) 18.9 \pm 3.31(P<0.01 v s$ adult); protein (55) $12.0 \pm 0.90$; and OA/P (55) $44.7 \pm 5.04$.

$\dagger P<0.05 v s \geqq 33$ wk.

$\ddagger P<0.01$ vs cord.

$\S P<0.05$ vs assisted ventilation, no BPD.

I $P<0.05$ vs no assisted ventilation.

Samples from 22 infants during the first $48 \mathrm{~h}$ of life demonstrated a significant correlation between GA and ceruloplasmin level both in protein content $(r=0.58, P<0.01)$ and in OA $(r$ $=0.63, P<0.01)$. In addition, the degree of activity exhibited by protein that was present was significantly correlated with GA both on $1-2 \mathrm{~d}(r=0.648, P<0.01)$ and on $3-5 \mathrm{~d}$ of life $(r=$ $0.513, P<0.01)$. That is, the more mature infants had a higher proportion of active protein.

Sequential samples were collected from 24 infants. It was noted that the seven infants who were $32 \mathrm{wk}$ of gestation or less exhibited a different time course when compared with the remainder of the infants. At 1-2 d, these smallest infants had significantly lower OA and protein. By 6-10 d they showed increases in both $\mathrm{OA}$ and protein, bringing them into the range observed for the remainder of the infants, with these increases being accompanied by an increasing proportion of active protein. The remainder of the infants (GA $\geq 33 \mathrm{wk})$, already at $1-2 \mathrm{~d}$, had a significantly higher $O A$ and activity ratio than cord samples and did not exhibit further increases in protein or activity during the period studied. Mean OA and mean protein remained well below adult levels throughout the study (3-17 d) in all infants. When infants were compared with regard to respiratory status, it was noted that babies who went on to develop BPD had significantly less active protein on 1-2 d than those infants who required assisted ventilation but did not develop BPD. In addition, $\mathrm{OA}$ and protein levels on 3-5 $\mathrm{d}$ were lower in infants on ventilators than in those not requiring assisted ventilation.

Alpha-1-antiprotease. Serum samples from 21 infants during the first $48 \mathrm{~h}$ of life demonstrated a significant correlation between GA and $\alpha$-1-AP, both in protein content ( $r=0.58, P<$ $0.01)$ and in TIC $(r=0.64, P<0.01)$. The mean activity ratio (TIC/protein) for all infants (Table 4) was $96.1 \%$ (range, 74$123 \%)$. This parameter did not correlate with GA.

A group of seven very immature infants $(\mathrm{GA}, \leq 32 \mathrm{wk}$, birth weight $<1300 \mathrm{~g}$ ), however, had levels of TIC and protein on 1$2 \mathrm{~d}$ significantly less than the more mature infants, and also significantly less than full-term cord values. In addition, when sequential samples were collected, these seven least mature infants exhibited a different time course than the remaining infants. TIC and protein were significantly higher at 3-5d than they had been at 1-2 d. The increase in protein concentration exceeded the increase in TIC, so that by $3-5 \mathrm{~d}$ there was a significantly higher level of protein than of TIC, resulting in an activity ratio significantly lower than that observed for more mature infants. When activity ratio was compared with GA at 3-5d, a significant correlation was observed $(r=0.66, P<0.01)$, indicating that the more mature infants had a higher proportion of active protein. By $6-10 \mathrm{~d}$ the less mature infants had protein levels and TIC within the normal range for healthy adults. The more mature infants had achieved adult levels of protein and TIC by $1-2 \mathrm{~d}$, and they did not exhibit further increases.

Several suggestive differences were found when infants were compared with regard to respiratory status. Infants on ventilators had decreased TIC on 3-5 d, and increased protein on 11-17 d, resulting in lower activity ratios than infants not requiring assisted ventilation. Babies who went on to develop BPD had lower $1-2 \mathrm{~d}$ TIC and protein levels and a lower 3-5 d activity ratio than infants on ventilators who did not develop BPD. 
Table 4. Alpha-1-antiprotease*

\begin{tabular}{|c|c|c|c|c|c|}
\hline & & \multicolumn{4}{|c|}{ Days of life } \\
\hline & & $1-2$ & $3-5$ & $6-10$ & $11-17$ \\
\hline \multirow[t]{4}{*}{ All infants } & TIC & $93.3 \pm 8.27$ & $101.5 \pm 6.03$ & $97.1 \pm 3.65$ & $99.3 \pm 7.33$ \\
\hline & Protein & $96.4 \pm 7.75$ & $113.1 \pm 6.04$ & $103.3 \pm 6.37$ & $111.4 \pm 8.41$ \\
\hline & $\mathrm{TIC} / \mathrm{P}$ & $96.1 \pm 2.99$ & $91.0 \pm 4.11$ & $98.6 \pm 5.51$ & $91.0 \pm 5.85$ \\
\hline & $(n)$ & $(21)$ & $(20)$ & (18) & (9) \\
\hline \multirow{4}{*}{$\begin{array}{l}\text { Gestational age } \\
\quad \leqq 32 \mathrm{wk}\end{array}$} & TIC & $56.4 \pm 6.95 \dagger$ & $75.0 \pm 8.46 \div$ & $91.7 \pm 6.60^{\S}$ & $93.7 \pm 5.89$ \\
\hline & Protein & $62.3 \pm 7.87 \dagger$ & $109.8 \pm 12.8^{\S}$ & $117.3 \pm 14.31$ & $135.0 \pm 12.7$ \\
\hline & $\mathrm{TIC} / \mathrm{P}$ & $91.3 \pm 6.78$ & $69.2 \pm 5.82^{\prime}$ & $82.8 \pm 9.92$ & $70.0 \pm 3.0$ \\
\hline & $(n)$ & (7) & (4) & (6) & (3) \\
\hline \multirow{4}{*}{$\begin{array}{l}\text { Gestational age } \\
\geqq 33 \text { wk }\end{array}$} & TIC & $111.7 \pm 8.26$ & $108.1 \pm 6.27$ & $99.8 \pm 4.34$ & $102.2 \pm 10.83$ \\
\hline & Protein & $113.4 \pm 7.57$ & $113.9 \pm 7.03$ & $96.5 \pm 5.97$ & $99.7 \pm 7.36$ \\
\hline & $\mathrm{TIC} / \mathrm{P}$ & $98.5 \pm 2.95$ & $96.5 \pm 3.90$ & $106.4 \pm 5.58$ & $101.5 \pm 3.76$ \\
\hline & $(n)$ & (14) & $(16)$ & (12) & $(6)$ \\
\hline \multirow[t]{4}{*}{ No assisted ventilation } & TIC & $106.4 \pm 10.19$ & $113.3 \pm 7.72$ & $97.7 \pm 4.98$ & $99.3 \pm 9.59$ \\
\hline & Protein & $106.4 \pm 10.57$ & $117.2 \pm 9.70$ & $95.2 \pm 7.59$ & $101.6 \pm 6.50$ \\
\hline & $\mathrm{TIC} / \mathrm{P}$ & $100.9 \pm 3.52$ & $99.2 \pm 4.95$ & $106.5 \pm 7.00$ & $97.4 \pm 5.16$ \\
\hline & $(n)$ & $(8)$ & (11) & $(10)$ & (7) \\
\hline \multirow[t]{4}{*}{ Assisted ventilation } & TIC & $85.2 \pm 11.5$ & $87.1 \pm 7.33$ & $96.4 \pm 5.71$ & $99.5 \pm 1.50$ \\
\hline & Protein & $90.2 \pm 10.65$ & $108.1 \pm 6.57$ & $113.8 \pm 10.24$ & $146.0 \pm 11.0$ \\
\hline & $\mathrm{TIC} / \mathrm{P}$ & $93.2 \pm 4.21$ & $81.1 \pm 5.43$ & $88.6 \pm 7.85$ & $68.5 \pm 4.50$ \\
\hline & $(n)$ & (13) & (9) & $(8)$ & $(2)$ \\
\hline \multirow{4}{*}{$\begin{array}{l}\text { Assisted ventilation } \\
\text { no BPD }\end{array}$} & Tic & $98.1 \pm 11.93$ & $96.0 \pm 8.10$ & $102.2 \pm 6.83$ & \\
\hline & Protein & $102.3 \pm 11.04$ & $108.2 \pm 6.28$ & $105.4 \pm 5.85$ & \\
\hline & TIC/P & $96.3 \pm 4.58$ & $88.8 \pm 5.15$ & $97.0 \pm 3.96$ & \\
\hline & $(n)$ & $(10)$ & (6) & (5) & $(0)$ \\
\hline \multirow{3}{*}{ BPD } & TIC & $42.3 \pm 10.74$ & $69.3 \pm 8.88$ & $86.7 \pm 8.57$ & $99.5 \pm 1.5$ \\
\hline & Protein & $50.0 \pm 8.33$ & $108.0 \pm 17.93$ & $127.7 \pm 26.62$ & $146.0 \pm 11.0$ \\
\hline & $\begin{array}{l}\mathrm{TIC} / \mathrm{P} \\
(n)\end{array}$ & $\begin{array}{l}82.7 \pm 8.67 \\
(3)\end{array}$ & $\begin{array}{l}65.7 \pm 6.49 \\
(3)\end{array}$ & $\begin{array}{l}74.7 \pm 19.15 \\
\text { (3) }\end{array}$ & $68.5 \pm 4.5$ \\
\hline
\end{tabular}

* Abbreviations: TIC, trypsin inhibitory capacity (\% adult pool) and P, protein (\% adult pool). Values are expressed as mean \pm SEM and $(n)$, number. Full-term cord samples: TIC (55) 83.6 \pm 3.44; protein (54) $87.0 \pm 2.98$; and TIC/P (54) $99.0 \pm 3.62$.

$\dagger P<0.01 v s \geqq 33 \mathrm{wk} ; \mathrm{p}<0.05$ vs cord.

$\ddagger P<0.01$ vs d $1-2$ (four pairs); $p<0.05$ vs Protein.

${ }^{\S} P<0.01$ vs $\mathrm{d} 1-2$.

' $P<0.05$ vs $\geqq 33 \mathrm{wk}$.

\section{DISCUSSION}

At birth, newborn infants are abruptly brought in to an oxygen rich extrauterine environment, necessitating dramatic physiologic adaptation. If birth is premature and RDS develops, drastic invasive measures are required, including even higher concentrations of oxygen and positive pressure ventilation. Uncomplicated RDS resolves by $48-72 \mathrm{~h}$ of life (31). Pathologic changes in the lungs associated with the treatment of RDS have been described as BPD (25). Changes begin at 48-72 h of life, with progression to Stage 4 changes and chronic lung disease after prolonged periods of therapy (22). Our study was designed to explore biochemical parameters related to oxygen exposure in order to further explain the susceptibility of newborn infants to the development of this lung disease. Studies of adult RDS, a syndrome with many features in common with neonatal lung disease (11), have defined several pathogenic mechanisms (26). These mechanisms include the following: 1) direct damage from oxygen exposure; 2) release of toxic oxygen radicals by the neutrophils and PAM that migrate to the lung during oxygen therapy; and (3) the uninhibited action of neutral proteases released by neutrophils and PAM, after $\alpha-1$-AP has been inactivated by oxygen exposure.

Several studies document extensive pathologic changes in the lungs of animals exposed to high concentrations of oxygen (4), and in vitro studies demonstrate the effects of oxygen on lung cell cultures. Damage to cells is mediated by highly reactive metabolites generated during the reduction of oxygen in biologic systems (33). Enzyme systems which generate these oxygen me- tabolites produce damage when instilled into rat lungs in vivo (17). Defenses against these radicals include enzymes (superoxide dismutase, catalase), plasma factors (ceruloplasmin, transferrin), trace elements $(\mathrm{Mn} \mathrm{Zn}, \mathrm{Cu}$ ), and vitamin $\mathrm{E}(5)$. The newborn infant, both immature and full-term, is deficient in the antioxidants ceruloplasmin and vitamin E $(8,14)$. Supplementation of vitamin $\mathrm{E}$ alone, however, has not been effective in protecting newborns against the development of BPD (27) nor in protecting lambs against oxygen toxicity (13).

A second mechanism that plays a role in the development of lung disease is the release of oxygen radicals by neutrophils and PAM $(15,24)$, which invade lungs in response to hyperoxia. Merritt's work with oxygen therapy in guinea pigs (21) documents the progression of initial epithelial damage followed by the appearance of neutrophils and then by the appearance of macrophages. In cell cultures, hydrogen peroxide released by neutrophils is cytotoxic to pulmonary tissues (33). Complement activation may augment neutrophil-mediated damage by causing neutrophil aggregation and intrapulmonary capillary sequestration (36). Neutrophil-aggregating activity in plasma (C5a and possibly kallikrein (29) is significantly correlated with the development of adult RDS (12). This factor has not been explored in neonatal lung disease.

Finally, neutrophils (37) and PAM (24) can secrete elastase, a proteolytic enzyme capable of digesting fibronectin and elastin, structural elements of the lung and its vasculature (28). Elastin is particularly important to the premature because it may be necessary for normal human lung development (16). In addition, elastase cleaves multiple plasma proteins, activating the coagu- 
lation, kinin, and complement systems with amplification of destructive agents. Leukocyte elastase activity has been found in the pulmonary lavage fluid of adults with RDS (18), and is higher in infants with RDS than in infants intubated for other causes, remaining elevated for up to $55 \mathrm{~d}$ in infants who developed BPD (21). $\alpha$-1-AP and alpha-2-macroglobulin are the two serum factors that inhibit the effects of elastase. It has been suggested that alpha-2-macroglobulin does not fully inhibit the destructive action of elastase (32). That $\alpha-1-\mathrm{AP}$ is the prime elastase inhibitor is supported by the finding that congenital deficiency of this inhibitor is associated with emphysema. $\alpha$-1-AP has decreased activity in neonatal RDS (20), and is itself inhibited by oxygen exposure $(2,3)$. The interaction of these three pathophysiologic forces is strikingly illustrated by the biochemical parameters observed on 3-5 d of life in our study of 69 newborn infants. Serum MDA, which reflects membrane lipid peroxidative damage, peaked at 3-5 d. This demonstrates that a measurable increase in peroxidation had occurred with respect to the already high MDA levels in cord blood. Surprisingly, infants on ventilators had somewhat lower levels of MDA in the first $5 \mathrm{~d}$ of life.

Premature infants had low levels of the antioxidant vitamin $\mathrm{E}$ through 3-5 d. These levels increased in all babies by $6-10 \mathrm{~d}$ of life without pharmacologic supplementation, but did not reach adult levels until the second week of life. Vitamin E levels were not, however, correlated with clinical status.

Ceruloplasmin, another major serum antioxidant, was also markedly lower than adult levels at 3-5 d, both in its OA and its protein concentration. This was particularly true of the least mature premature infants. The degree of activity exhibited by that protein which was present was correlated with GA, indicating that the least mature infants had the least active protein at 3-5 $\mathrm{d}$ of life. In addition, infants on ventilators had less OA and ceruloplasmin protein on 3-5 $\mathrm{d}$ than the remaining infants.

As with ceruloplasmin, the proportion of active $\alpha$-1-AP protein correlated with GA at 3-5 d, indicating that the least mature babies were at greatest risk for uninhibited protease activity, especially because infants $\leq 32$ wk gestation are born with low levels of $\alpha$-1-AP. This immature group included those who subsequently developed BPD. The comparison of $\alpha$-1-AP activity levels and protein levels on 3-5 d supports the concept of oxygen mediated inactivation of this essential protease inhibitor. Infants on ventilators had less active protein than non-ventilated babies, and those infants who subsequently developed BPD had less active protein than the other ventilated babies. Ceruloplasmin is the plasma antioxidant most important in protecting $\alpha$-1-AP from oxidative inactivation (35). As we have shown, ceruloplasmin levels are low in all newborns.

All infants demonstrate lipid peroxidation in the newborn period as manifested by elevated levels of serum MDA. Our data demonstrate that a number of interacting mechanisms render the very small premature infant particularly susceptible to oxygen-related tissue damage, with one outcome being the development of BPD. Small premature infants, and especially those on ventilators, were markedly deficient in ceruloplasmin, a major serum antioxidant. In addition to direct toxicity, oxygen exposure via assistsed ventilation inactivates $\alpha$-1-AP, leaving infants without protection against the action of proteolytic enzymes. Very small prematures are particularly at risk in this regard because they are born with low levels of $\alpha$-1-AP.

\section{REFERENCES AND NOTES}

1. Avery, M. E., Fletcher, B. D., and Williams, R. G.: Hyaline membrane disease. In: The lung and its disorders in the newborn infant. pp. 228-37 (WB Saunders, Philadelphia, 1981).

2. Bruce, M. C., Boat, T. F., Martin, R. J., Dearborn, D. G., and Fanaroff, A. Inactivation of alpha-1-proteinase inhibitor in infants exposed to high concentrations of oxygen. Am. Rev. Respir. Dis., (abstract) 123 suppl: 166 (1981).

3. Carp, H. and Janoff, A.: Potential mediator of inflammation. Phagocytederived oxidants suppress the elastase-inhibitory capacity of alpha-1-proteinase inhibitor in vitro. J. Clin. Invest., 66: 987 (1980).
4. Deneke, S. M. and Fanburg, B. L.: Normobaric oxygen toxicity of the lung. N. Engl. J. Med., 303: 76 (1980)

5. Dormandy, T. L.: Free-radical oxidation and antioxidants. Lancet, $i: 647$ (1978).

6. Dubowitz, L. M. S., Dubowitz, V., and Goldberg, C.: Clinical assessment of gestational age in the newborn infant. J. Pediat. 77: 1 (1970).

7. Edwards, D. K.: Radiographic aspects of bronchopulmonary dysplasia. J. Pediatr. 95: 823 (1979).

8. Ehrenkranz, R. A.: Vitamin E and the neonate. Am. J. Dis. Child., 134: 1157 (1980).

9. Fabianek, J., DeFilippi, J., Rickards, T., and Herp, A.: Micromethod for tocopherol determination in blood serum. Clin. Chem., 14: 456 (1968).

10. Fox, R. B., Hoidal, J. R., Brown, D. M., and Repine, J. E.: Pulmonary inflammation due to oxygen toxicity: Involvement of chemotactic factors and polymorphonuclear leukocytes. Am. Rev. Respir. Dis., 123: 521 (1981).

11. Hallman, M., Spragg, R., Harrell, J. H., Moser, K. M., and Gluck, L.: Evidence of lung surfactant abnormality in respiratory failure. J. Clin. Invest., 70:673 (1982).

12. Hammerschmidt, D. E., Weaver, L. J., Hudson, L. D., Craddock, P. R., and Jacob, H. S.: Association of complement activation and elevated plasmaC5a with adult respiratory distress syndrome. Lancet, $i$ : 947 (1980).

13. Hansen, T. N., Hazinski, T. A., and Bland, R. D.: Vitamin E does not prevent oxygen-induced lung injury in newborn lambs. Pediatr. Res., 16: 583 (1982).

14. Hillman, L. S.: Serial serum copper concentrations in premature and SGA infants during the first three months of life. J. Pediatr. 98: 305 (1981).

15. Hocking, W. G. and Golde, D. W.: The pulmonary-alveolar macrophage I. N. Engl. J. Med., 301: 580 (1979).

16. Inselman, L. S. and Mellins, R. B.: Growth and development of the lung. J. Pediatr. 98: 1 (1981).

17. Johnson, K. J., Fantone, J. C., Kaplan, J., and Ward, P. A.: In vivo damage of rat lungs by oxygen metabolites. J. Clin. Invest., 67: 983 (1981).

18. McGuire, W. W., Spragg, R. G., Cohen, A. B., and Cochrane, C. G.: Studies on the pathogenesis of the adult respiratory distress syndrome. J. Clin. Invest., 69: 543 (1982).

19. Mancini, G., Carbonara, A. O., and Heremans, J. F.: Immunochemical quantification of antigens by single radial immunodiffusion. Immuno-chemistry, 2: 235 (1965).

20. Mathis, R. K., Freier, E. F., Hunt, C. E., Krivit, W., and Sharp, H. L.: Alpha1 -antitrypsin in the respiratory-distress syndrome. N. Engl. J. Med., 288: 59 (1973).

21. Merritt, T. A.: Oxygen exposure in the newborn guinea pig lung lavage cell populations, chemotactic and elastase response: a possible relationship to neonatal bronchopulmonary dysplasia. Pediatr. Res., I6: 798 (1982).

22. Merritt, T. A., Stuard, I. D., Puccia, J., Wood, B., Edwards, D. K., Finkelstein, J., and Shapiro, D. L.: Newborn tracheal aspirate cytology: classification during respiratory distress syndrome and bronchopulmonary dysplasia. $\mathrm{J}$. Pediatr. 98: 949 (1981).

23. Miller, R. G.: Simultaneous Statistical Inference. pp. 1-8, 31-35, 67-70 (McGraw-Hill Book Company, New York, 1966).

24. Nathan, C. F., Murray, H. W., and Cohn, Z. A.: The macrophage as an effector cell. N. Engl. J. Med., 303: 622 (1980).

25. Northway, W. H., Rosan, R. C., and Porter, D. Y.: Pulmonary disease following respirator therapy of hyaline-membrane disease. Broncho-pulmonary dysplasia. N. Engl. J. Med., 276: 357 (1967).

26. Rinaldo, J. E. and Rogers, R. M.: Adult respiratory-distress syndrome. N. Engl. J. Med., 306: 900 (1982).

27. Saldanha, R. L., Cepeda, E. E., and Poland, R. L.: The effect of vitamin E prophylaxis on the incidence and severity of bronchopulmonary dysplasia. J. Pediatr. 101: 89 (1982).

28. Sandberg. L. B., Soskel, N. T., Leslie, and J. G.: Elastin structure, biosynthesis, and relation to disease states. N. Engl. J. Med., 304: 566 (1981).

29. Schapira, M., Despland, E., Scott, C. F., Boxer, L. A., and Colman, R. W.: Purified human plasma kallikrein aggregates human blood neutrophils. J. Clin. Invest., 69: 1199 (1982).

30. Schosinsky, K. H., Lehmann, H. P., and Beeler, M. F.: Measurement of ceruloplasmin from its oxidase activity in serum by use of o-dianisidine dihydrochloride. Clin. Chem., 20: 1556 (1974).

31. Stahlman, M. T.: Acute respiratory disorders in the newborn. In: G. B. Avery: Neonatology. Pathophysiology and management of the newborn. pp. 378-9 (J. B. Lippincott Co., Philadelphia, 1981).

32. Stone, P. J., Calore, J. D., Snider, G. L., and Franzblau, C.: Role of alphamacroglobulin-elastase complexes in the pathogenesis of elastase-induced emphysema in hamsters. J. Clin. Invest., 69: 920 (1982).

33. Suttorp, N. and Simon, L. M.: Lung cell oxidant injury. Enhancement of polymorphonuclear leukocyte-mediated cytotoxicity in lung cells exposed to sustained in vitro hyperoxia. J. Clin. Invest., 70: 342 (1982).

34. Talamo, R. C., Bruce, R. M., Langley, C. E., Berninger, R. W., Pierce, J. A. Brant, L. J. and Duncan, D. B.: Alpha-1-antitrypsin laboratory manual. DHEW Publication \# (NIH)78-1420. (US Government Printing Office, Washington, DC, 1978).

35. Taylor, J. C. and Oey, L.: Ceruloplasmin: Plasma inhibitor of the oxidative inactivation of alpha-1-protease inhibitor. Am. Rev. Respir. Dis., 126: 476 (1982).

36. Till, G. O., Johnson, K. J., Kunkel, R., and Ward, P. A.: Intravascular activation of complement and acute lung injury. J. Clin. Invest., 69: 1126 (1982).

37. Weissman, G., Smolen, J. E., and Korchak, H. M.: Release of inflammatory 
mediators from stimulated neutrophils. N. Engl J. Med, 303.27 (1980).

38. Yoshioka, T., Kawada, K., Shimada, T., and Mori, M.: Lipid peroxidation in maternal and cord blood and protective mechanism against activated-oxygen toxicity in the blood. Am. J. Obstet. Gynecol., 135: 372 (1979).

39. The authors wish to express our gratitude to Dr. Margaret Karpatkin for her instructive discussion and criticism of this work, to Frank Gonzalez for his technical assistance and to Carol Seaman for her help in organizing our data. 40. Requests for reprints should be addressed to: Dr. David Hart, Department of Pediatrics, New York University Medical School, 550 First Avenue, New York City, NY 10016

41. Received for publication March 1, 1983.

42. Accepted for publication July 20, 1983.

\title{
Methylprednisolone Resistance of Cystic Fibrosis Lymphocytes
}

\author{
E. LANGHOFF, ${ }^{(11)}$ P. S. PEDERSEN, AND C. KOCH \\ Medical Department P [E.L.] and Department of Pediatrics TG, State University Hospital (Rigshospitalet) \\ [P.S.P., C.K.], Copenhagen, Denmark
}

\section{Summary}

In the current study, the in vitro viability and resistance to methylprednisolone (MP) was investigated in lymphocytes from patients with cystic fibrosis (CF) and normal controls. The addition of MP to phytohemagglutinin-stimulated lymphocyte cultures inhibits the proliferative response in a dose-dependent way. The dose response curves to MP were similar in CF cultures and controls $(P>0.05)$. Neither preincubation nor pulse exposure to $M P$ revealed any difference between normal and $C F$ lymphocytes.

Skin fibroblasts from patients with $\mathrm{CF}$ have been reported to show increased resistance to the toxic effect of dexamethasone (1-3, 5-6). This study was undertaken to investigate the suppressive effect of glucocorticoids on another cell culture system using MP on phytohemagglutinin-stimulated lymphocytes.

\section{Abbreviations}

CF, cystic fibrosis

cpm, counts per minute

MP, methylprednisolone

PHA, phytohemagglutinin

\section{MATERIALS AND METHODS}

Isolation of mononuclear cells. Peripheral blood lymphocytes were isolated from $10 \mathrm{CF}$ patients aged 9-14 yr (nine males and one female and 10 age- and sex-matched controls. Informed consent was obtained from the parents. Ten milliliters heparinized venous blood was added to equal amounts of Hank's balanced salt solution. The mononuclear cells were isolated on Lymphoprep (Nyco, Norway) and washed three times in Hank's balanced salt solution. The cells were then resuspended in RPMI1640 (Gibco, Europe), containing 10\% fetal calf serum, 500 IU penicillin per ml (Leo, Denmark), and streptomycin, $333 \mu \mathrm{g} / \mathrm{ml}$ (Novo, Denmark). The final cell concentration was adjusted to $1 \times 10^{6}$ cells per $\mathrm{ml}$ cell suspension.

Lymphocyte cultures. Both CF and control cultures were set up 1) with direct addition of PHA and MP and 2) after preincubation of cultures for $24 \mathrm{~h}$ before PHA and MP addition. Additionally, the effect of pulse exposure of cells was studied by incubation with $\mathrm{MP}, 2.5 \mu \mathrm{g} / \mathrm{ml}$ cell suspension for $20 \mathrm{~min}$ followed by washing of the cells before 3 ) direct addition of PHA and MP, and 4) preincubation for $24 \mathrm{~h}$, as above.
Incubation and harvesting. The cultures were incubated in microtiter plates $\left(5 \times 10^{4}\right.$ cells per well) with MP (Urbason, Hoechst, F.R.G.) at a final concentration range of $0-0.06-0.30-$ $1.2-3.0-12-30 \mu \mathrm{g} / \mathrm{ml}$ cell suspension and PHA (Difco, Detroit, USA) $50 \mu \mathrm{g} / \mathrm{ml}$ cell suspension. The incubation continued for $72 \mathrm{~h}$ at $+37^{\circ} \mathrm{C}$ followed by another $20 \mathrm{~h}$ period after $\left[{ }^{14} \mathrm{C}\right]$ thymidine addition ( $20 \mathrm{nCi}$ per well, Amersham, UK) before harvesting. The $\left[{ }^{14} \mathrm{C}\right]$ thymidine uptake was measured in a liquid scintillation counter (Packard, Tri-Carb, Liquid Scintillation Spectrometer). The mean number of counts incorporated in the presence versus absence of steroid was expressed as the per cent suppression at each concentration level. Group means were compared using Student's $t$ test.

\section{RESULTS}

The effect of MP addition to PHA-stimulated CF and control cultures is shown in Figure 1. MP cause a dose-dependent inhibition of radiolabeled thymidine incorporation in cell DNA. The dose response curves to MP are similar with only minor insignificant differences between $\mathrm{CF}$ and control cultures at any concentration level $(P>0.05)$. The PHA responses in the absence of $\mathrm{MP}$ were the same for $\mathrm{CF}$ and control cultures $8.6 \times 10^{3} \mathrm{cpm}$

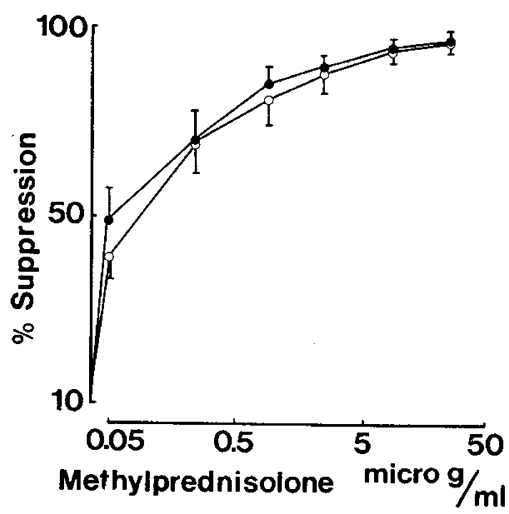

Fig. 1. Suppression of $\left[{ }^{14} \mathrm{C}\right]$ thymidine uptake in phytohemagglutininstimulated lymphocytes by methylprednisolone. (O) Cystic Fibrosis patients and $(\mathbf{)}$ controls. SEM is indicated. 